\title{
Contribution Of Deposit Money Banks To Economic Growth In Nigeria
}

\author{
(1994-2017)
}

\author{
Dr Abolade Francis AKINTOLA *, Olubukunmi Adeboye ADESANYA ** \\ ${ }^{*}$ Department of Finance, Babcock University, Ilishan-Remo,Ogun State, Nigeria. \\ ** Department of Finance, Babcock University, Ilishan - Remo, Ogun State, Nigeria . \\ DOI: 10.29322/IJSRP.11.01.2021.p10995 \\ http://dx.doi.org/10.29322/IJSRP.11.01.2021.p10995
}

\begin{abstract}
Over the years, the Nigerian banking industry has become deep and experienced and there has been a high level of improvement and development, but the economic growth has not attained the same level attained by the banking industry, hence, the reason for this study which focussed on the relationship between deposit money banks (DMBs) and economic growth in Nigeria from 1994 to 2017. The study was carried out on secondary data obtained from real gross domestic product (RGDP), money supply $\left(\mathrm{M}_{2}\right)$, bank credit (BC) and interest rate (INT).

Data was sourced from the Central Bank of Nigeria statistical bulletin and National Bureau of Statistics annual report. Regression analysis was applied to estimate the relationship between deposit money banks (DMBs) and economic growth, while Ordinary Least Square (OLS) method was used to estimate the model with the aid of econometric view (E-view). Results obtained from the study showed that deposit money banks through money supply, credit to private sectors and interest rate charged on lending to borrowers significantly impacts on economic growth in Nigeria. The study therefore recommends that Central Bank of Nigeria should direct deposit money banks to make bank charges and interest rate to be at moderate level to enable manufacturers and other productive sectors of the economy to have access to credit at affordable rate. The study further recommends that government through supervision and regulation should make people have banking confidence in the banking system of Nigeria.
\end{abstract}

Index Terms- Central Bank of Nigeria, deposit money banks, economic growth, real gross domestic product, bank credit and interest rate.

\section{INTRODUCTION}

$I^{\text {nom }}$ mportance of the banking sector in the development of any economy cannot be overemphasized, and this is due largely to the fact that all other sectors of the economy, be it: manufacturing, oil and gas, real estate, mining to mention but few, all depend on the banking sector for their survival. Thus, the issue of contribution of deposit money banks on Nigeria's economic growth and development is very important. Banks in developed and developing countries are expected to play vital and effective roles in financing economic projects and activities in order to ensure sustainable economic growth. Banking industry credit in Nigeria assumed a new dimension and was transformed by the recapitalization and consolidation of banks which restructured them for better performance.

Access to bank credit or financing can be said to have improved significantly in response to competition and the healthy state the banks attained. As a result, credit availability increase which allowed manufacturing companies to increase production, output and efficiency and in turn increase the profitability of banks through various services rendered from which they generate income (Abdulsalam, 2013).

Financial institutions channel resources from the surplus economic units to the deficit units for investment purposes. This is inform of provision of loans and advances to the private and public institutions for the growth of domestic output and promotion of the export trade, agricultural production and provision of infrastructure .

The role of financial institutions in economic growth has attracted the attention of researchers and policy makers . There is a large body of literature both empirical and theoretical, which have examined this issue. The findings of these studies are not without controversy. While some studies established that financial institutions have been instrumental in accelerating economic growth, others have stated that it has not been very significant . According to Beck, Levine and Loayza(2000), a long list of scholars posit a causal association between finance and economic growth .

Levine (2006) and Beck (2009)argued that the positive effect of financial institutions over economic growth can be explained by five (5) mechanisms whose operations reduce the negative impact of information asymmetries among economic agents and the transaction costs involved in their activities . According to them, financial institutions provide means of payment that facilitate a greater number of transactions ; concentrates the savings of a large number of savers, make possible the allocation of resources to their most productive economic use through the effective evaluation and monitoring of investment projects ;improves corporate governance ; and contributes to risk management.

Studying the impact of deposit money banks on the growth of the Nigerian economy has become very necessary . Economic 
growth has long been considered as an important goal of economic policy with substantial body of research dedicated to explaining how this goal can be achieved .But such concerted efforts of researchers and polices have yielded no meaningful result . Central Bank of Nigeria in 2009 noted that flow of credit to the priority sectors fell short of prescribed targets and failed to impact positively on investment, output and domestic price level . From the foregoing, there appears to be a cause for concern . One can ask a question as to if deposit money banks have aided the growth and development of the Nigerian economy ? This study attempt to provide an answer .

\section{LITERATURE REVIEW}

This section presents review of literatures relating to the study .

\subsection{Conceptual Review}

\subsection{Deposit Money Bank}

Deposit money banks have traditionally played an important role in financing various sectors of the economy especially in developing nation like Nigeria. This is because deposit money banks involved in financial intermediation process which entails chanelling funds from the surplus units to the deficit units of the economy, thus transforming bank deposits into loans or credit (Ujah \& Amaechi ,2005). Deposit money banks function in various dimensions in economy which include : acceptance of deposit from customers for safekeeping, lending to customers ,provision of loans and overdraft, discounting bills of exchange . It is important to state that of all these functions mentioned, deposit money banks major operation is the acceptance of deposits and granting of loans to customers . An efficient financial intermediation function of deposit money bank will boost the micro-economic growth process which is the productive capacity of the economy. Aliyu and Yusuf (2013) reasoned that a developed financial sector should reflect the ease of entrepreneurs with sound projects to obtain financial resources and the confidence with which investors anticipate adequate returns .

\subsubsection{Bank Credit}

Bank credit is the borrowing capacity provided to an individual by the banking system in the form of credit or a loan . The total bank credit the individual has is the sum of the borrowing capacity each bank provides to the individual. Credit is the extension of money from the lender to the borrower . Sunny(2013) noted that credit implies a promise by one party to pay another for money borrowed or goods and services received. Credit cannot be divorced from the banking sector as banks serve as a conduit for funds to be received in form of deposits from the surplus units of the economy and passed on to the deficit units who need the funds for productive purposes. Banks are therefore debtors to the depositors of funds and creditors to the borrowers of funds .

\subsubsection{Economic Growth}

Traditionally, many economists and other professionals failed to make clear distinction between the concept of economic growth and economic development, thereby generating debate in literature . Some scholars considered economic development as a process that generate economic and social, quantitative and particularly qualitative changes, which cause the economy to cumulatively and durably increase its real nominal product . In contrast and compared to development, economic growth is therefore a narrower concept than economic development , because the former is in a limited sense, is an increase of the national income per capital and involves the analysis, especially in quantitative terms of this process, the functional relations between the endogenous variables. In a wider sense, it involves the increase of gross domestic product(GDP), gross national product (GNP) and National Income (NI), including the production capacity expressed both in absolute and relative size ,per capital, encompassing also the functional modification of the economy. Economic growth could therefore be seen as all the process of measuring the size of national economics, the macroeconomic indications, especially the GDP per capital, in an ascendant but not necessarily linear direction, with positive effects on the economic-social sector, while development shows growth impacts on the society by increasing the standard of life (Oshadami,2006).

\subsection{Theoretical Review}

\subsubsection{Theory of Financial Intermediation}

Besley and Bringham (2009) emphasised that the presence of intermediaries improves economic well-being. They further explained that financial intermediaries were created to fulfil specific needs of both savers and borrowers, and to reduce the inefficiencies that would otherwise exist if users of funds could get loans only by borrowing directly from savers. Finance is required for different purposes by different people, organizations , and other economic agents . To provide the needed finance, there are varieties of institutions rendering financial services . Deposit money banks are among such institutions that render financial services. They are mainly involved in financial intermediation, or indirect financing which involves channelling funds from surplus unit to the deficit unit of the economy, thus transforming bank deposits into loans and credits.There are businesses that have good ideas and business opportunities they would want to invest money in , but they do not have money. They would be willing to borrow from the net savers who have idle funds. For this reason ,these second groups are called net borrowers or the deficit unit of the economy . However, there are barriers that make it difficult for the borrowing to take place. And to remove this barrier, there is therefore a need for an intermediary (a-gobetween) who will play the role of bridging the gap between the net savers and net borrowers. This role is called financial intermediation. Financial intermediation is the role of channelling money from net savers who have idle funds to investor or net borrowers who are in need of funds .

\subsubsection{Supply Leading Theory}

Schumpeter (1934) was first to report the link between finance and economic growth and this has been an issue of controversy in both developed and developing economies. The supply-leading theory assumes that financial development is the driver of economic growth. The theory postulates that the existence of financial institutions like deposit money banks /commercial banks and the supply of their financial assets , liabilities and related financial services in advance of demand for them would provide efficient allocation of resources from surplus 
units to deficit units, thereby leading the other economic sectors in their growth process .

\subsubsection{Loan Pricing Theories}

Stiglitz and Weiss developed this theory in 1981. The theory indicates that banks always set high interest rates. According to the proponents, banks should consider the moral hazards and adverse selection problems in the credit market when maximizing interest income giving the high credit market information asymmetry. When high interest rate is set by banks, it will trigger adverse selection problem in the market as high risk borrowers are willing to accept these high rates. Upon receiving this loans and advances, the borrower may develop moral hazard behaviours or so called borrower moral hazard since they are likely to take on highly risky projects or investment s .

\subsection{Empirical Review}

Nwanyanwu (2008) used ordinary least square econometric technique to assess the impact bank credit on economic growth in Nigeria. The study used Gross Domestic Product and the aggregate domestic credit to the economy as proxies for dependent and independent variable respectively. Based on the finding of the study, it was observed that banks credit has not impacted significantly on the growth of the Nigerian economy. This was attributed to the fact that banks exhibited apathy in lending to the private sector for productive purposes e.g agricultural sector .As a result of this, the volume of loan actually advanced to investors is insignificant .

Dada (2014) examined the significance of bank credit in stimulating output within the real sector of the economy . The study employed bivariate and multivariate models by Tang (2003) in the study of thirteen (13)African countries on financial development and growth . Real Gross Domestic Product growth was used as proxy for economic growth value while real private sector credit growth represented the banks credit and independent variable in the study. The study observed that there exists a reverse causation between real output and financial development . In other words, real output causes financial development but not vice versa.

Sanusi and salleh (2007) examined the relationship between financial development and economic growth in Malaysia covering the period of $1960-2002$. Three(3)measures of financial development were used, namely ratio of broad money to GDP , credit provided by the banking system, and deposit money banks to GDP. By employing the autoregressive distributed lag approach , the study found that ratio of broad money to GDP , and credit provided by the banking system have positive and statistically significant impact on economic growth in the long run . The result further indicated that a rise in investment will enhance economic growth in the long run .

Dalhat and Hassan (2016) in their study examined the role of deposit money banks in financing SMEs in Nigeria . Secondary data were extracted and entered into the data view and analysed thereafter . Record of financial support, business environment and managerial skills were extracted and analysed using the linear regression analysis and the multiple regression analysis for the purpose of testing the hypothesis. As for the primary data analysis , the univariate analysis technique was used to obtain the mean and standard deviation to see the level of inclination to the scale
.The study recommended that government should as a matter of urgency assist prospective SMEs to have access to finance and necessary information relating to business opportunities, modern technology, raw materials, market, plant and machinery which would enable them to reduce their operating costs and be more efficient to meet the market competition.

Jatau ,Ali and Ashami (2016) in their study analyzed the impact of deposit money banks' credit on investment in Nigeria . Time series data for thirty one year period 1981 to 2012 was analyzed using ordinary least square (OLS) regression technique with the aid of E-view to test the hypotheses formulated in line with the objectives of the study .Unit root, variance inflation factor (VIF) and Heteroskedacity white test were used for data stationarity and diagnosis. The empirical results of their study shows that both total deposit money banks credit and interest rate exert a positive and significant impact on investment in Nigeria . However ,the result of the interest rate is at variance with the $a$ priori expectation. Considering the empirical result, the study concludes that deposit money banks' credit to the private sector should be sustained as it is a viable source of finance to the private sector of the Nigerian economy. The study therefore recommended that greater efforts should be made to make available more medium and long term loans to the productive sectors such as the manufacturing sector, agricultural sector and SMEs as they constitute integral growth process . Also interest rate on credit facility granted to private sector should be significantly reduced.

\section{Methodology}

Research design adopted for this study is ex-post facto . This is because the event has already taken place. Secondary data obtained from the Statistical Bulletin published annually by the Central Bank of Nigeria (CBN) and publications of the National Bureau of Statistics (NBS) were used for this study. The data covered a period of twenty four (24)years from 1994 to 2017.

Method of data analysis adopted for the study is Ordinary Least Square (OLS) .This method is adopted to determine contribution of deposit money banks to economic growth in Nigeria from 1994 to 2017 . Econometric views (E-views) software package will be applied to statistically measure the relationship .

The model to capture contribution of deposit money banks to economic growth in Nigeria is stated below ;

$\mathrm{RGDP}=\beta \mathrm{o}+\beta_{1} \mathrm{MS}+\beta_{2} \mathrm{INT}+\beta_{3} \mathrm{BC}+\mu$

Where :

RGDP $=$ Real Gross Domestic Product

MS =Money Supply

INT $=$ Interest Rate

$\mathrm{BC}=$ Bank Credit

$\beta \mathrm{o}=$ Intercept

$\beta_{1}-\beta_{3}=$ Partial slope of the variables

$\mu=$ Stochastic error term which represents other independent

variables not included

in the model . 


\section{Data PREsentation and Analysis}

To achieve the objective of this study i.e contribution of deposit money banks to economic growth in Nigeria, secondary data on real gross domestic product (RGDP), money supply (MS), bank credit (Credit) and interest rate (INT) were collected from CBN statistical bulletin for period between 1994 to 2017 i.e 24 years.
To bring interest rate to the same level with real gross domestic product (RGDP), bank credit (Credit) and money supply (MS), log of these variables were obtained. The data were analysed in two folds, namely: the descriptive analysis which described the obtained data; and empirical analysis where the regression analysis estimates are shown.

Descriptive Statistics :

The descriptive statistics of the research data is presented and discussed below:

Table one

\begin{tabular}{|l|l|l|l|l|}
\hline & LOGRGDP & LOGM2 & LOGCREDIT & INT \\
\hline mean & 10.43461 & 7.592569 & 7.291965 & 18.74187 \\
\hline median & 10.41403 & 7.620906 & 7.129747 & 18.13500 \\
\hline maximum & 11.14221 & 9.846986 & 9.834895 & 29.80000 \\
\hline minimum & 9.884314 & 4.710542 & 4.062561 & 13.54000 \\
\hline Std.Dev & 0.449859 & 1.646771 & 1.807414 & 3.308716 \\
\hline skewness & 0.202743 & -0.140370 & -0.025800 & 1.672841 \\
\hline kurtosis & 1.522735 & 1.691473 & 1.711658 & 6.619876 \\
\hline & & & & \\
\hline Jarque-Bera & 2.346731 & 1.791057 & 1.662488 & 24.29709 \\
\hline probability & 0.309324 & 0.408392 & 0.435507 & 0.000005 \\
\hline & & & & \\
\hline sum & 250.4306 & 182.2217 & 175.0072 & 449.8050 \\
\hline Sum Sq. Dev. & 4.654580 & 62.37266 & 75.13515 & 251.7948 \\
\hline
\end{tabular}

Source: Author's computation using E-views 9

From the results descriptive statistic above, there is evidence of significant variation in the trends of the variables within the period of consideration. This is shown by the differences between the maximum and the minimum of all the variables.

The probability of the Jarque-Bera statistic for both interest rate is very low and leads to rejection of the null hypothesis of a normal distribution, further confirming that the Skweness and kurtosis of the sample data does not match a normal distribution and suggesting that the data series for interest rate is not normally distributed. However, since the probability of the Jarque-Bera statistics for LOGRGDP, LOGM2, and LOGCREDIT are insignificant, it leads to acceptance of the null hypothesis of a normal distribution, indicating that the Skweness and kurtosis of each of the sample data match a normal distribution, and suggesting that the data series for the variables are normally distributed. 
Table Two

\begin{tabular}{|c|c|c|c|c|c|}
\hline & & Money Supp & conomic $\mathrm{Gr}$ & & \\
\hline & $\begin{array}{l}\text { One } \\
x_{1}+\mu\end{array}$ & Coefficients & Standard Er & t-statistic & prob \\
\hline 1 & (Constant) & 8.401759 & 0.089719 & 93.64493 & 0.0000 \\
\hline & LOGM2 & 0.267742 & 0.011559 & 23.16300 & 0.0000 \\
\hline & $\begin{array}{l}\text { ependent } \mathrm{Va} \\
96 . \mathrm{F}=536.5\end{array}$ & $\begin{array}{l}\text { LOGRGDP } \\
.000<0.05\end{array}$ & & $\mathrm{P}=8.4017-$ & \\
\hline
\end{tabular}

Source: Author's computation using Eviews 9

Research objective here sought to evaluate the impact of money supply by deposit money banks on economic growth. The results in table two above shows that money supply by deposit money banks, proxied by LOGM2 has a significantly positive impact on economic growth as shown by the coefficient of LOGRGDP 0.2677) and the significant p-value of 0.000 which is less than 0.05 .

Also, the magnitude of impact stands at just $26.77 \%$, that is, a $1 \%$ increase in money supply by deposit money banks will increase real GDP by almost $27 \%$. Furthermore, the $\mathrm{R}^{2}$ value of 0.9696 shows that about $96 \%$ changes in real GDP is explained by money supply. Furthermore, the entire model is significant in explaining the impact of money supply by deposit money banks on economic growth in Nigeria as depicted by the F-Statistic of 536.5 and with a p-value of $0.000(<0.05)$.

Table Three

\begin{tabular}{|l|l|l|l|l|}
\hline \multicolumn{2}{|c|}{ Interest Rate and Economic Growth } & Standard Error & Prob. \\
\hline $\begin{array}{c}\text { Model Two } \\
\mathrm{Y}=\mathrm{a}_{0}+\beta_{2} \mathrm{X}_{2}+\mu\end{array}$ & Coefficients & & \\
\hline & & & \\
\\
\cline { 2 - 5 }
\end{tabular}

Source: Author's computation using Eviews 9

Research objective above sought to ascertain the effect of interest rate charged by deposit money banks on economic growth. The results in table three above shows that interest rate significantly and negatively influences economic growth as shown by the positive coefficient of INT $(-0.066)$ and the significant pvalue of 0.0166 which is less than 0.05 .

Also, the magnitude of impact stands at just $6.6 \%$, that is, a $1 \%$ increase in interest rate will cause economic growth to fall by
$6.6 \%$. furthermore, the $\mathrm{R}^{2}$ value of 0.2339 shows that only $23 \%$ changes in economic growth is explained by changes in interest rate. Furthermore, the entire model is significant in explaining the effect of the interest rate on economic growth as depicted by the F-Statistic value of 6.717 and with a significant p-value of 0.0166 $(<0.05)$. 
Table Four

\begin{tabular}{|c|c|c|c|c|}
\hline \multicolumn{5}{|c|}{ Banks' credit and Economic Growth } \\
\hline $\begin{array}{l}\text { Model Three } \\
\mathrm{Y}=\mathrm{a}_{0+\beta 3} \mathrm{X}_{3+} \mu\end{array}$ & Coefficients & Standard Error & t-statistic & prob \\
\hline (Constant) & 8.650014 & 0.072511 & 119.2930 & 0.0000 \\
\hline LOGM2 & 0.244735 & 0.009664 & 25.32566 & 0.0000 \\
\hline \multicolumn{5}{|c|}{$\begin{array}{l}\text { a. Dependent Variable: } \text { LOGRGD } \\
\mathrm{r}^{2}=0.9668, \mathrm{~F}=641.38, \mathrm{p}=0.000<0.05\end{array}$} \\
\hline
\end{tabular}

Source: Author's computation using Eviews 9

Research objective above sought to determine the effect of the deposit money banks' credit on economic growth. The results in table four above shows that banks' credit, proxied by LOGCREDIT significantly and positively influences economic growth as shown by the positive coefficient of LOGCREDIT $(0.2447)$ and the significant $p$-value of 0.0000 which is less than 0.05 .

Also, from the results, the magnitude of the significant impact stands at about $25 \%$, that is, a $1 \%$ increase in banks' credit will cause an increase in economic growth by up to $25 \%$. Furthermore, the $\mathrm{R}^{2}$ value of 0.9668 shows that about $97 \%$ changes in economic growth is explained by changes in banks' credit. Furthermore, the entire model is significant in explaining the effect of deposit money banks' credit on economic growth as depicted by the FStatistic value of 641.4 and with a significant p-value of 0.000 which is less than 0.05 .

\section{DISCUSSION OF FINDINGS}

From the descriptive statistics, we find that as pre-supposed by theory, real GDP, banks' credit to private sector, and money supply by deposit money banks are normally distributed as shown by the insignificant value of the Jarque-Berra statistic.

Also, the empirical analysis of the first model showed that the coefficient of money supply in the model was positive and significant which led to the rejection of the null hypothesis and the conclusion that money supply by deposit money banks has a significantly positive impact on the economic growth of Nigeria. However, the level of impact was low as given by the coefficient which was just about $27 \%$. The value of the intercept was positive and significant, rightly indicating that asides money supply by deposit money banks, there are other factors that affect economic growth. This finding conforms to a-priori and further substantiates the fact that when money is made available in an economy, it improves economic activities as well as economic growth. This finding is consistent with the works of Khan, Qayyum and saheed (2005)who examined the relationship between financial

This publication is licensed under Creative Commons Attribution CC BY.

http://dx.doi.org/10.29322/IJSRP.11.01.2021.p10995 development and economic growth for 159 countries over the period 1960-1999 using the two stage least squares (2SLS) and found that financial development has a positive and statistically significant effect on economic growth. The findings are also consistent with the work of Sanusi and Salleh (2007) who examined the relationship between financial development and economic growth in Malaysia covering the period 1960-2002 using ratio of broad money to GDP as a measure and found that ratio of broad money to GDP has a positive and statistically significant impact on economic growth in the long run.

Furthermore, the results of the estimated second model showed that the coefficient of interest rate in the model was consistent with a-priori, negative and significant which led to the rejection of the null hypothesis of significant impact, and thus, the conclusion that the interest rate charged by deposit money banks has a significant but negative impact on economic growth. However, the level of impact was also very low as given by the coefficient of $6.6 \%$. the value of the intercept was positive and significant, rightly indicating that asides interest rate, there are other factors that affect economic. This finding conforms to a-priori and therefore suggests that when interest rate rises, it will reduce investment and reduce economic growth.

Finally, the result in the third model showed that the coefficient of bank credit in the model was also positive and significant which led to the conclusion that banks' credit significantly impacts economic growth . The positive level of impact was also very low as given by the coefficient of $25 \%$. The value of the intercept was also positive and significant, rightly indicating that asides credit from deposit money banks, there are other factors that affect economic growth. This finding conforms to a-priori and shows that for every naira of credit given to the private sector by deposit money banks, investment is boosted and hence economic growth is enhanced. This finding is consistent with the work of Ali , Jatau and Ashami (2016)who analyzed the impact of the Deposit money banks' credit on investment in Nigeria .

In summary, the overall finding of this study suggests that deposit money banks through its supply of money, credit to 
private sector, and interest rate charged, significantly impacts economic growth, therefore, the continuous development of deposit money banks and financial sectors in general would go a long way in improving the economy of Nigeria .

\section{CONCLUSION}

Deposit money banks are prime mover of economic growth of any country as they provide financial assistance, support and services to different sectors of the economy. This study sought to examine the relationship between deposit money banks and economic growth in Nigeria from 1994 to 2017 . The findings of the study suggests that deposit money banks through its supply of money, credit to private sectors and interest charged on lending to borrowers, significantly impacts on economic growth in Nigeria . For the reason discuss above, Federal Government of Nigeria (FGN) through Central Bank of Nigeria (CBN) with effective regulation and supervision can make deposit money banks to contribute more to economic growth and development of Nigeria from the monetary and credit policies issued to deposit money banks every two years .

The result of this study is in agreement with similar study carried out by Sanusi and Salleh (2007) which stated that credit provided by the banking system has positive and significant impact on economic growth in the long run .

5.1 Recommendations

In line with the findings and conclusion of this study, the following recommendations are made :

1. Central Bank of Nigeria $(\mathrm{CBN})$ should direct banks to make bank charges and interest rate to be at moderate level to enable manufacturers and other productive sectors of the economy to have access to credit so that in the course of obtaining credit to finance production , interest element will not shoot up cost of production thereby making the price of locally produced goods to be high compared to imported goods .

2. Through monetary and credit guidelines issued by the Central Bank of Nigeria every two years, specific percentage of total bank credit should be assigned to manufacturing and other productive sectors of the economy. Monitoring team of both Central Bank of Nigeria and Nigerian Deposit Insurance Corporation should ensure that deposit money banks meet the specified rate. Any deposit money bank that does not meet the specified rate by way of credit granted to their customers should be sanctioned by the monetary authority

3. Central Bank of Nigeria should encourage deposit money banks to increase their lending activities to less preferred sectors of the economy on the ground that such lending will be fully guaranteed by the government to avoid the issue of bad and doubtful debt . This policy will help diversify the economy for greater prospects and development .

4. In order to encourage owners of private businesses to take advantage of credit facilities, deposit money banks should be encouraged to set up Financial Advisory Services Unit (FASU) to advise and enlighten entrepreneurs of the need to borrow from banks to develop their business .

Government should encourage transparency within the banking sector in order to instil banking confidence in people because a lot of Nigerians still prefer to keep the money at home instead of bank. This is because of banks failure witnessed by them. Where there is no banking confidence in the people, a lot of money will be outside the banking system and this will affect credit to be granted and government will not be able to use money supply to control the economy .

\section{REFERENCES}

[1] Abdulsalam, I (2013). Impact of banking sector development on economic growth : Another look at evidence from Nigeria . Journal of Business Management and Social Sciences Research ; 2(4) ,49-57.

[2] Aliyu,M .\& Yusuf, A.H .(2013). Impact of private sector credit on real sector of Nigeria . International Journal of Business and Social Research vol . 3 (5); 105-116.

[3] Beck, T. (2009). The econometric of finance and growth . The Palmgrave Handbook of Econometrics, Basingstone ; Palmgrave .

[4] Beck, T. , Levine, R. \& Loayza , R. (2000) .Finance and sources of growth Journal of Financial Economics ; 58 (1-2), 261- 300.

[5] Besley, J. \&Bringham , H. (2009). Principles of Finance . South Western Centage Leaning, USA.

[6] Dada, R. M. ((2014). Commercial banks' credit and SMEs development in Nigeria . An empirical review . International Journal of Review ; 1(8), 305320 .

[7] Dalhat, B. S. \&Hassan, N. M.(2016). The role of money deposit banks in financing small and medium scale enterprises in Nigeria . Middle Eastern Finance and Economics , 8; $146-152$.

[8] Jatau, S . ,Ali, J. I. \&Ashami, P. I. (2016) . Deposit money banks' credit and investment drive of developing economies. Empirical evidence from Nigeria . Asian Journal of Agricultural Extension, Economics \& Sociology, 11 (1), $1-12$.

[9] Khan ,M. A.,Qayyum, A. \& Saheed ,A. S.(2005). Financial development and economic growth : The case of Pakistan. The Pakistan Development Review , 44(2), 819- 837

[10] Levine , R, (2006). Finance and growth :The theory , evidence and mechanisms . Handbook of Economic Growth : North Holland ; Elsevier .

[11] Nwanyanwu, O.J.(2008). An analysis of banks' credit on Nigerian economy growth. Jos Journal of Economics, 4(1), 45 -55.

[12] Oshadami , O, L . (2006). The impact of domestic debt on Nigeria's economic growth . Unpublished B .Sc project .

[13] Sanusi, N .A. \&Salleh ,N. H.M,(2007). Financial development and economic growth in Malaysia . An application of ARDL approach .

[14] Schumpeter, J. A.(1934). The theory of economic development :An inquiry into profits ,capital, credit, interest and business cycle . Cambridge Mass : Harvard University Press.

[15] Stiglitz , J.E.\& Weiss, A .(1981) .Credit rationing in markets with imperfection information.American Economic Review 7(3); 393 -410 .

[16] Sunny, I. O.(2013). T he impact of commercial banks' credit to agriculture on agricultural development in Nigeria . An econometric analysis . International Journal of Business, Humanities and Technology ; 3(1), 85 94

[17] Ujah,N.I. \&Amaechi, A. E. (2005). Money , banking and finance in a developing world. Cheeda Global Print, Aba .

\section{AUTHORS}

First Author - Dr Abolade Francis AKINTOLA

Department of Finance, Babcock University, Ilishan-Remo, Ogun State, Nigeria., E-mail: akintolaa@babcock.edu.ng GSM:08023563670 
Second Author - Olubukunmi Adeboye ADESANYA

GSM :08028709401

Department of Finance, Babcock University, Ilishan - Remo,

Ogun State, Nigeria.E- mail : Boyebukunmi2012@gmail.com

\section{APPENDIX 1}

TABLE FIVE

\begin{tabular}{|c|c|c|c|c|}
\hline YEAR & LOGRGDP & LOGM2 & LOGCREDIT & INT \\
\hline 1994 & 9.90 & 5.44 & 4.97 & 21.00 \\
\hline 1995 & 9.92 & 5.67 & 5.19 & 20.18 \\
\hline 1996 & 9.96 & 5.85 & 5.47 & 19.74 \\
\hline 1997 & 9.99 & 6.02 & 5.76 & 13.54 \\
\hline 1998 & 10.01 & 6.19 & 5.86 & 18.29 \\
\hline 1999 & 10.02 & 6.44 & 6.07 & 21.32 \\
\hline 2000 & 10.07 & 6.78 & 6.27 & 17.98 \\
\hline 2001 & 10.14 & 7.15 & 6.64 & 18.29 \\
\hline 2002 & 10.27 & 7.32 & 6.84 & 24.85 \\
\hline 2003 & 10.36 & 7.58 & 7.00 & 20.71 \\
\hline 2004 & 10.46 & 7.66 & 7.26 & 19.18 \\
\hline 2005 & 10.53 & 7.88 & 7.52 & 17.95 \\
\hline 2006 & 10.60 & 8.24 & 7.74 & 17.26 \\
\hline 2007 & 10.67 & 8.54 & 8.21 & 16.94 \\
\hline 2008 & 10.74 & 8.99 & 8.85 & 15.14 \\
\hline 2009 & 10.82 & 9.15 & 9.12 & 18.99 \\
\hline 2010 & 10.91 & 9.31 & 9.23 & 17.59 \\
\hline 2011 & 10.96 & 9.41 & 9.27 & 16.02 \\
\hline 2012 & 11.00 & 9.54 & 9.59 & 16.79 \\
\hline 2013 & 11.05 & 9.63 & 9.66 & 16.72 \\
\hline 2014 & 11.11 & 9.78 & 9.75 & 16.28 \\
\hline 2015 & 11.14 & 9.85 & 9.83 & 16.93 \\
\hline 2016 & 13.18 & 11.97 & 11.94 & 18.15 \\
\hline 2017 & 13.85 & 12.54 & 12.39 & 18.85 \\
\hline
\end{tabular}

Source: Computed from CBN Statistical Bulletin 2017 